\title{
Atrial fibrillation in patients with mitral regurgitation
}

\author{
-Zrinka Planinić' ${ }^{*}$ \\ 일orko Perčić', \\ (1)Ante Pašalić', \\ -1Tea Friščić', \\ DDario Gulin', \\ (CLeon Adrović', \\ (DDijana Bešić', \\ (1DJozica Šikić1,2
}

'University Hospital "Sveti Duh", Zagreb, Croatia

${ }^{2}$ University of Zagreb School of Medicine, Zagreb, Croatia
RECEIVED:

April 30, 2018

ACCEPTED:

May 10, 2018
KEYWORDS: atrial fibrillation, mitral regurgitation, coronary artery disease.

CITATION: Cardiol Croat. 2018;13(5-6):186. | https://doi.org/10.15836/ccar2018.186

*ADDRESS FOR CORRESPONDENCE: Zrinka Planinić, Klinička bolnica „Sveti Duh“, Sv. Duh 64, HR-10000 Zagreb, Croatia. / Phone: +385-91-3714-308 / E-mail: zrinkaplaninic@gmail.com

ORCID: Zrinka Planinić, https://orcid.org/0000-0001-8664-3338 • Marko Perčić, https://orcid.org/0000-0001-7904-8899 Ante Pašalić, https://orcid.org/0000-0001-5989-6495 • Tea Friščić, https://orcid.org/0000-0003-3189-8661 Dario Gulin, https://orcid.org/0000-0001-8502-7816 • Leon Adrović, https://orcid.org/0000-0002-0555-6863 Dijana Bešić, https://orcid.org/0000-0001-9701-0253• Jozica Šikić, https://orcid.org/0000-0003-4488-0559

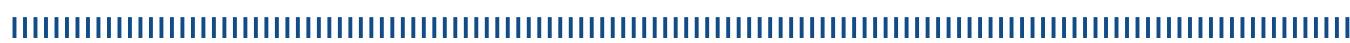

Background: Mitral regurgitation (MR) is often complicated with atrial fibrillation (AF), with estimated rate of $5 \%$ per year. Patients with both MR and AF have higher risk of cardiac events ${ }^{1}$. The aim of our study was to investigate how many of patients with MR have AF, and is there any correlation with the severity of MR and AF occurrence.

Patients and Methods: Retrospective study was conducted to investigate frequency of AF in patients with MR. A total number of 686 patients were included, $45 \%$ were female. The prevalence of arterial hypertension, diabetes mellitus, hyperlipidemia were similar between men and women. When compared to women, men smoke more frequently. On the other hand, women had higher serum uric acid levels.

Results: Atrial fibrillation was found in $44 \%$ of patients with MR. Almost half of women (49.5\%) and $39.5 \%$ of men with MR had AF. Paroxysmal AF was present in $38.7 \%$, and permanent in $27.4 \%$ of patients with MR. $45 \%$ of patients had mild, $36.4 \%$ had moderate, and $18.6 \%$ had severe MR. $25.5 \%$ of men and $18.3 \%$ of women had concomitant AF and severe MR. Mitral regurgitation was associated with AF and coronary artery disease in $16.2 \%$ of cases, with $53 \%$ having mild MR.

Conclusion: Atrial fibrillation can often be found in patients with mitral regurgitation. Mild MR was more often associated with AF occurrence, as well as in patients with both AF and CAD.

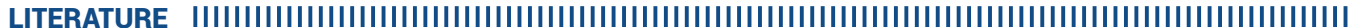

1. Herrmann $\mathrm{HC}$, Gertz ZM, Silvestry FE, Wiegers $\mathrm{SE}$, Woo $\mathrm{YJ}$, Hermiller $\mathrm{J}$, et al. Effects of atrial fibrillation on treatment of mitral regurgitation in the EVEREST II (Endovascular Valve Edge-to-Edge Repair Study) randomized trial. J Am Coll Cardiol. 2012 Apr 3;59(14):1312-9. https://doi.org/10.1016/j.jacc.2011.12.023 